\title{
Rhinocerotidae (Mammalia) from the Late Miocene of Bulgaria
}

Denis GeraAds, Paris, and NikOlaÏ Spassov, Sofia

With 3 plates, 3 figures and 7 tables.

\section{Zusammenfassung}

Wir Beschreiben die Resten von Rhinocerotiden aus etwa zehn Obermiozän Lokalitäten in Bulgarien. Die wichtigsten Fundorte sind Kalimantsi, Hadjidimovo und derjenige kurz erfundene in Strumyani. Mindestens sieben Arten werden wegen Elementen vom Schädel repräsentiert. Ein Schädel mag zu Chilotherium kiliasi gehören, eine Art, für welche eine neue Untergattung, Eochilotherium, etabliert wurde. Einige Stücken gehören zu Ch. (Chilotherium). Man erreicht in Bulgarien der westlichen Grenze der Entdeckung dieser Gattung. Acerorhinus wird sehr oft in Kalimantsi gefunden, aber dieser Gattung soll wiedergearbeitet werden. Eine unerwartete Entdeckung von Brachypotherium in Ahmatovo ist die letzte in Europa. Die hornige Rhinos Ceratotherium und Dihoplus liegen beiden in zwei Lokalitäten. Diese taxonomische Mannigfaltigkeit bedeutet die Anwesenheit von verschiedenen Umgebungen, denn die Lagerungen ziemlich derselben Alters sind. Es entspricht der geographische Lage von Bulgarien, wo die Gebiete von asiatischen Chilotherium, von der pontische Acerorhinus und von der Balkan-Iraner Ceratotherium überschneiden. Dazu kommt die wahrscheinliche Einwanderung von Brachypotherium aus Afrika zu Europa.

\footnotetext{
Abstract

We describe the remains of Rhinocerotidae from about 10 Late Miocene localities of Bulgaria, the main ones being Kalimantsi and Hadjidimovo, and the newly discovered site of Strumyani. At least seven species are represented, mostly by cranial elements. A skull is assigned to Chilotherium kiliasi, a species for which a new sub-genus, Eochilotherium, is established. Some fragmentary remains are referred to Ch. (Chilotherium), which reaches in Bulgaria the westernmost limit of its range. Acerorhinus is well represented at Kalimantsi, but this genus probably deserves revision. An unexpected discovery is that of Brachypotherium at Ahmatovo, its latest known occurrence in Europe. The horned rhinos, Ceratotherium and Dihoplus, co-occur at two localities. This relatively great diversity points to a variety of environments, as it is unlikely that the main fossil faunas are very different in age. It also reflects the geographic position of Bulgaria, where the ranges of the mainly Asiatic Chilotherium, of the Pontic Acerorhinus and of the Balkano-Iranian Ceratotherium overlap, in addition to a possible immigration of Brachypotherium from Africa into Europe.
} 
K e y - w o r d s : Rhinocerotidae, Mammalia, Late Miocene, Bulgaria, Balkans

S c h 1 ü s s e 1 w ö r t e r : Rhinocerotidae, Mammalia, Obermiozän, Bulgarien, Balkan

Addresses of the authors: DENIS GERAADS, CNRS UPR 2147, 44 rue de l'Amiral Mouchez, 75014 Paris, France

NiKOlaÏ SPASSOv, National Museum of Natural History, Tsar Osvoboditel 1, 1000 Sofia, Bulgaria

\section{Contents}

Zusammenfassung - Abstract

Introduction

Fossil localities

Systematic Palaeontology

Conclusions

\section{Introduction}

Until now, the Miocene Rhinocerotidae of Bulgaria have been known only through a few outdated works, such as the early papers of BAKALOV $(1933,1939)$, a brief description by Nikolov \& KovacheV (1966) and the monograph of BAKAlov \& NiKOlOV (1962). Since then, more discoveries, and large-scale excavations conducted mainly in the areas of Hadjidimovo (Mesta River valley), Kalimantsi and recently at Strumyani (Struma River valley), all in southwestern Bulgaria, have significantly improved the collections. A summary of our present knowledge of the main faunal associations is given in SPASSOV et al. (2006). Furthermore, several recent papers dealing with upper Miocene rhinos of the area (HEISSIG 1975, 1996, 1999; KAYA \& HeISSIG 2001, GerAads 1988, 2005; GERAADS \& KoufOS 1990; ForTELIUS et al. 2003; GiaOURTSAKIS 2003; GIAOURTSAKIS \& HeISSIg 2004; GiaOURTSAKIS et al. 2006) have shed new lights on the evolution of this family. The present paper is an attempt to revise all available material, stored in the National Museum of Natural History, Sofia (NMNHS), in its Assenovgrad Museum branch (NMNHA), and in the Department of Geology, University of Sofia (DGUS). It is compared with other Late Miocene to Recent rhinos, stored in the Natural History Museum, London (BMNH); Faculté des Sciences, Lyon (FSL); Hessisches Landesmuseum, Darmstadt (HLMD); National Museums of Kenya, Nairobi (KNM); Musée Géologique et Minéralogique, Lausanne (MGML); Macedonian Museum of Natural History, Skopje (MMNH); Muséum National d'Histoire Naturelle, Paris (MNHNP); Maden Tetkik ve Arama Museum, Ankara (MTA); Naturhistorisches Museum Basel (NHB); Naturhistorisches Museum, Wien (NHMW); National Museum of Ethiopia, Addis Ababa (NME); 
Paläontologisches Institut, Münster (PIUM); Senckenberg Museum, Frankfurt (SMF); Staatliches Museum für Naturkunde, Stuttgart (SMNS).

\section{Fossil localities (Text-fig. 1)}

Most of the material of Rhinocerotidae comes from the richest Bulgarian Late Miocene fossiliferous sites: Hadjidimovo and Kalimantsi. Detailed studies of the fauna from both these localities started recently (KOVACHEV 1988, 2001; SPASSOV \& GINSBURG 1999; GERAADS et al. 2001, 2003, 2005b, 2006; KostopOulos et al. 2001; SPASSOV 2002; HristOVA et al. 2002a \& b; Hristova \& KovacheV 2005; Koufos et al. 2003; MARKOv 2004a \& b; Spassov \& GeraAdS 2004; SPASSOV et al. 2006).

\section{Hadjidimovo}

Hadjidimovo is situated in the Mesta river valley, East of the Pirin ridge, not far from the Greek border. Four fossiliferous sites are known, the most important of which being Hadjidimovo-1 (Hadjidimovo-Girizite), with light clayey sands belonging to the Nevrokop formation (VATSEV 1980). It yielded more than 20000 fossils (NMNHA) belonging to about 30 mammal species, including the rhinos described below, making it one of the richest Late Miocene sites of the Eastern Mediterranean and peri-Pontic areas. Although the Hadjidomovo site (unknown locality) was first mentioned by NiKOLOV $(1973,1985)$, this huge collection was mostly accumulated and cared for, thanks to the efforts of D. KOVACHEV, mainly between 1985 and 1998. Hadjidimovo-1 could be earlier than Pikermi, as indicated by the evolutionary stages of Mesopithecus (Koufos et al. 2003) Hipparion (Cremohipparion) mediterraneum (HRISTOVA \& Spassov 2005), Adcrocuta eximia (pers. obs. N.S.), and the presence of Tragoportax rugosifrons (SPASSOV \& GERAADS 2004). SPASSOV (2002) suggested that the locality could be dated to the MN11/MN12 boundary.

All materials from Hadjidimovo are stored in NMNHA.

\section{Kalimantsi}

The Late Miocene deposits around the Kalimantsi village, on the western side of the Pirin ridge, in the Middle Struma basin, cover a large area (ca. $6 \mathrm{~km} 2)$ with more than 10 known fossiliferous spots, scattered over a vertical distance of about $100 \mathrm{~m}$. The recent revision of their biochronology demonstrates that all Kalimantsi sites are of Turolian age. Kalimantsi-1 (the river bank), belonging to the newly established Gradishte genetic lithocomplex, is more likely to yield a fauna of early Turolian age. Hipparion cf. macedonicum is known only from this level. The other Kalimantsi faunas (referred to the Strumyani genetic lithocomplex) are considered to belong to the middle Turolian (SPASSOV et al. 2006), probably slightly older than the Pikermi fauna, according to the evolutionary stages of Hipparion (Cremohipparion) mediterraneum and 


\section{H. (Hippotherium) brachypus (Hristova \& KovACHEV 2005). Gazella sp.,}

H. (Cremohipparion) mediterraneum and H. (Hippotherium) brachypus dominate in these levels. Tragoportax cf. amalthea, Palaeoreas lindermayeri, Helladotherium duvernoyi, Bohlinia attica, Adcrocuta eximia, Mesopithecus pentelicus are also well represented (SPASSOV et al. 2006). Presently, at least 34 species are known from Kalimantsi (all localities combined). Some specimens of Rhinocerotidae from Kalimantsi were mentioned and illustrated by BAKALOV \& NiKOLOV (1962); they are stored in DGUS. New materials collected by D. KovACHEV and coworkers, mostly from Kalimantsi-1, are stored in NMNHA.

\section{Strumyani}

The new rich locality Strumyani-2, near Sandanski in the Struma River valley, that we excavated in 2002-2003, has not been published in detail, but is likely to be of the same broad age (Turolian), probably early Turolian or first half of the middle Turolian, from the Hipparion assemblage (L.HRISTOVA, pers. comm.).

Some other localities have yielded only a few fossils.

\section{Central part of Western Bulgaria, Sofia region}

A quarry near Staniantsi in the Godech region (N.-W. Bulgaria), near the Serbian border, yielded only a fragment of incisor. The fauna might be Turolian (NIKOLOV 1985; SPASSOV 2002; MARKOV 2004b). It yielded unpublished mandibular teeth similar to those of Tapirus balkanicus from Balsha (SPASSOV \& GinsBURG 1999) that can be referred to the T. pannonicus - T. balkanicus group and also indicate an ante-Pliocene age for the locality.

\section{Struma river basin, S-W Bulgaria}

Some localities yielded fragmentary rhino remains, but very little is known about the geologic context. A rhino incisor comes from the coal-rich levels, at a depth of about $200 \mathrm{~m}$, of the Oranovo quarry near Simitli (south of Blagoevgrad), eponym locality of the newly established Oranovo genetic lithocomplex, probably of early Upper Miocene age.

Two rhinoceros finds were discovered near Slatino, north of Blagoevgrad. The deposits of the Slatino genetic lithocomplex are also considered as belonging to the lower part of the Upper Miocene (TZANKOV et al. 2005). Their precise provenance (most probably two different fossiliferous spots) is unknown. Their matrix is a grey-green gravellite clay concretion most probably washed by fluent waters. Such kind of clays, typical for the Slatino genetic lithocomplex (SPASSOV et al. 2006) crop out in several places around Slatino village.

At Kromidovo, not far from Kalimantsi, the fossils come from a spot in the village, but we could not locate it during our 2005 survey. The presence of Mesopithecus pentelicus (KoufOS et al. 2003; SPASSOV et al. 2006), would point to an age close to MN12, but the 
measurements of the specimens do not quite match those of the Pikermi sample, and this age estimate is far from secure.

\section{Maritsa and Tundja river basins, middle part of Southern Bulgaria}

A number of Upper Miocene fossiliferous spots are known from the Cherkezitsa River valley near Plovdiv, between the villages Seltsi, Bogdanits and Ahmatovo (NIKOLOV \& KOVACHEV 1966). All of them could be approximately contemporaneous. The richest mammal fauna is from the sand quarry of Ahmatovo, the most important locality in the Maritsa River basin (BAKAlov \& NiKolov 1962; NiKOlov \& KovacheV 1966). These authors reported Gomphotherium angustidens, but it is in fact Choerolophodon (TASSY 1983). DRAGOMANOV et al. (1981) referred the fossiliferous spots of the quarry to three different stratigraphic levels, but our observations do not confirm this stratigraphic subdivision, and age differences must be minimal. The revised list of the proboscideans from Ahmatovo is: Deinotherium gigantissimum, "Mammut" cf. borsoni, Choerolophodon pentelici, Tetralophodon atticus, Anancus sp. (MARKOV 2004b). As the genus Anancus appears in Bulgaria and Europe probably in the middle Turolian but in post-Pikermi time (SPASSOV et al. 2006) and Choerolophodon is not definitely known in the late Turolian, the age of Ahmatovo could be the second half/the end of the middle Turolian (MN12). The Brachypotherium skull and isolated teeth of an old individual described below are from the Ahmatovo quarry itself, while the isolated P4 of the same genus is from the deposits of the river-bank of Tcherkezitsa between Seltsi and Ahmatovo, stratigraphically slightly lower, but probably not much older.

In 1988 some small bovid, small giraffid and rhinos remains were discovered in the yard of the coachbuilder in the town of Yambol (on Tundja river). The Neogene deposits along the Tundja River belong to the Elhovska formation (KOJUMDJIEVA et al. 1984), the age of which ranges from the Maeotian to the Dacian-Romanian.

\section{Systematic Palaeontology}

Order Perissodactyla OwEN, 1848

\section{Family Rhinocerotidae GRAY, 1821}

We must stress again that the systematics of fossil rhinos is strongly defective, mainly due to the lack of comparative descriptions and diagnoses. We urge future workers to follow the recommendations of CIFELLI \& KIELAN-JAVOROWSKA (2005), and give differential diagnoses, of which we tried to provide some drafts, in the hope that these might serve as a basis.

Uppercase denotes upper teeth, lowercase denotes lower teeth. Measurements are in $\mathrm{mm}$, and follow GUÉRIN (1980). Measurements of tooth rows are at occlusal level, measurements of isolated teeth are maximum. 


\section{Genus Chilotherium RINGSTRÖM, 1924}

Ty p e-s p e c i e s : Chilotherium anderssoni RINGSTRÖM, 1924: 26. Late Miocene of China.

D i a g n o s i s : Both sexes hornless. Straight nasals. Frontal region depressed, forming a shallow fossa. Parietal crests wide apart. Maxilla flat or slightly depressed, facial crest and nasal notch far from orbit. Premaxillae forming two thin vertical walls, lacking incisors. Lower jaw with widened symphysial part and large tusk-like i2, separated by a broad diastema. Permanent dental formula: I 0/1(2) C0/0 P 3/3 M3/3; deciduous dental formula DI 0/2 DC 0/0 DP 4/3(4). Antecrochet long. Body low and stout, belly low above ground. Limbs much shortened. Manus and pes tridactyl with short, diverging metapodials. Lateral metapodials obliquely directed backwards (mostly translated from RINGSTRÖM 1924).

\section{Sub-genus Eochilotherium nov. subgen.}

Ty p e -s p e c i e s : Aceratherium kiliasi GERAADS \& KOUfOS, 1990.

D i a g n o s i s : supra-orbital process somewhat inflated, post-orbital process weak. Antecrochet moderate. Mandibular symphysis slightly broadened, incisors of plesiomorphic condition, close in structure to the i2 of Aceratherium / Acerorhinus (see below), not strongly enlarged, with subtriangular cross-section, with rounded border between the lateral and the ventral surfaces, which are subequal in width.

We reluctantly create this new sub-genus, because there are already too many names for European hornless rhinos, but it lacks several of the derived features which define the nominal sub-genus, C. (Chilotherium), which includes e.g., C. anderssoni from China, C. persiae from Maragha, and C. schlosseri from Samos. These apomorphic characters are: 1) lack of upper incisors; 2) enlarged flattened lower incisors, inserted wide apart in a broadened symphysis, with an upturned mesial (internal) edge - this is perhaps the most important apomorphic feature, unique to this group (see below for a more detailed description); 3) no supra-orbital process, and a well-marked postorbital one; 4) short premolars; 5) very long antecrochet; 6) brachypodial limbs. Most of these characters were already listed in the original diagnosis (RINGSTRÖM 1924:26). In C. (Eochilotherium), in which we include C. (Eochilotherium) kiliasi and C. (E.) samium (see below), the premolars are also short, but (1) and (6) are unknown, the lower incisors are medium-sized, with plesiomorphic characters (GERAADS \& KOUFOS 1990, pl. 2, fig. 5), the symphysis is only moderately broadened, there is a strong supra-orbital process but no postorbital one, and antecrochet is moderate. We agree with HeISSIG $(1996,1999)$ and FORTELIUS et al (2003) that these species can best be taken as primitive Chilotherium, but we prefer to keep them as taxonomically separate from the highly derived members of this group. 
Ty pe locality: Pentalophos, Greece, late Vallesian (MN 10) ? (see GERAADS \& Koufos 1990: figs. 1-7; pl. 2, figs. 1-5; pl. 3, figs. 1 \& 4; non pl. 3, figs 2, 3, 5).

Specific diagnosis: Nasal notch V-shaped, ante-orbital depression shallow. Zygomatic arches relatively weak. Upper incisors unknown. Cement present on premolars and molars. Antecrochet short. Long persisting di2, resulting in a hexaprotodont dentition even in old individuals. Diastema short (modified from GERAADS \& KOUFOS 1990 ).

Mat e ri a 1: unnumbered partial skull, with M3 erupting, lacking the cranial vault and pre-dental portion, from Kromidovo, DGUS (P1. 1, Figs. A-B).

Description: Only the ventral part of the skull is preserved. The zygomatic arches form an even curve, without sharp bend at the level of the glenoid fossa. The cranial basis is narrow. The premolars are small relative to the molars (measurements: table 1). All teeth have a long crochet, and a weak antecrochet, but small tubercles in the median valley, best expressed on M1, may represent its lingual extensions. The premolars have a moderate lingual cingulum, and the hypocone of P3 has a small mesial spur, but the median valley remains wide open. There is a distinct paracone fold, and the labial wall of the ectoloph is less flattened than in typical Chilotherium.

Comparison and discussion: We refer this specimen to C. (E.).cf. kiliasi on the basis of the close similarity in size and morphology of the teeth with those of a maxilla from Pentalophos (GERAADS \& KOUFOS 1990, fig. 2), but we are well aware that cheek-teeth alone are not a very sound basis for species identification. GERAADS \& KOUFOS (1990) described as A. kiliasi a sample of skulls and mandibles that FoRTELIUS et al. (2003) showed to be heterogeneous. Indeed, the mandible PNT-142 has large premolars and is not anteriorly broadened, and must belong to a different species (see below). A. kiliasi, of which the best specimen from Pentalophos is PNT 12 (GERAADS \& KoufOs 1990, pl. 3, fig. 3-4), was referred to Chilotherium by HEISSIG $(1996,1999)$ and ForTELIUS et al (2003), who also referred some material from Sinap to this species. They considered it to be close to C. samium (WEBER, 1905), from Samos, a species that was excluded from Chilotherium by GERAADS \& KOUFOS (1990) on the basis of WEBER'S description. Since the type material of C. samium is lost, there will indeed always remain a doubt about the identity of the species, but sound hypotheses must be based upon actual specimens. Thus, our understanding of C. samium is based upon a skull from Samos, SMF-M3601, labelled as such by K. HEISSIG. Both species lack the apomorphic features of C. (Chilotherium) listed above, and are better referred to a separate sub-genus.

FORTELIUS et al. (2003) thought that C. samium is close to C. wimani RINGSTRÖM, 1924, from China, but the published material of $C$. wimani does show the apomorphic features of the 
nominotypical subgenus, especially the huge lower incisors inserted on a much broadened symphysis (RINGSTRÖM 1924, fig. 28 and pl. 8, fig. 1).

\section{Sub-genus Chilotherium RINGSTRÖM, 1924}

Ty p e-s p e c i e s : Chilotherium anderssoni Ringström, 1924. Late Miocene, China.

D i g n o s is : Supra-orbital process may be present but weak; post-orbital process wellmarked. Lower jaw with strongly widened symphysial part. Antecrochet very long. Lower incisors (i2) long and very large, with triangular cross-section. The flat narrow latero-ventral face (lateral in other rhinos) is slightly broadened towards the base, and separated from the medioventral one by a sharp edge. The large dorso-lateral and medio-ventral ones are strongly broadened towards the base; their common edge forms the cutting edge, kept sharp by attrition with the upper lip, and dorso-medially oriented.

\section{Chilotherium cf. sarmaticum KOROTKEVICH, 1958}

Ty pe loc a lity: Berislav, Ukraine, late Vallesian or early Turolian.

D i a g n o s is : a small and less cursorial chilothere; parietal crests wider apart than in other chilotheres; nasals short; antecrochet moderate; metapodials less massive and limbs more shortened than in other species; talus usually with only two calcanear facets (simplified from KOROTKEVICH 1958b and 1970).

Mat e ri a 1: i2 from Oranovo; perhaps a fragment of incisor from the quarry near Staniantsi.

Description: The crown of the Oranovo incisor is slightly curved. The tooth is flattened, of regular width. The cross section is triangular, even at the base. The dorso-lateral surface lacks enamel, as in other Chilotherium s. str., and is slightly concave, abruptly becoming narrower towards the apex. It is separated from the slightly convex medio-ventral surface by a dorso-medial edge much sharpened by wear, but with a distinct prominence at its base. A third, ventro-lateral surface is flat or even slightly concave, and delimited by two clear keels from the other surfaces. It is of almost even width towards the base. This third surface is not so sharply delimited and becomes broader towards the base in the tusks of the larger species of Chilotherium. Measurements: max. basal width of the wear surface $\sim 39 \mathrm{~mm}$., crown length $=78$ (restored $\sim 86 \mathrm{~mm}$.), max. root diameter $=35 \mathrm{~mm}$., width of ventro-lateral surface $\sim 12 \mathrm{~mm}$.

Chilotherium sarmaticum was first described from Berislav, Ukraine (KOROTKEVICH $1958 \mathrm{a} \& \mathrm{~b} ; 1970)$. Although not discussed in the synonymy lists of the chilotheres published by HeISSIG $(1975,1999)$, this species is smaller than the currently accepted taxa from the Turkey and Eastern Europe. The Oranovo incisor is also smaller than the large chilothere species from Grebeniki and Maragha (SPASSOV et al. 2006). Berislav has been referred to MN11a by 
KorotKeVich (1988; Vallesian for this author), to the late Vallesian by DE BRUIJN et al. (1992), or to the early Turolian by KRAKHMALNAYA (1996). The morphology described by

KOROTKEVICH (1970) indicates a still less cursorial locomotory apparatus for Ch. sarmaticum than for other true chilotheres of the open spaces and the faunal analysis made by this author shows a more forested habitat in Berislav than in other localities of the same region such as Grebeniki and Novaya Emetovka. This would also be in good agreement with a Vallesian age. The Oranovo incisor is also virtually identical in shape and size with Ch. cf. sarmaticum described from Reghiu, Romania, a locality that was assigned to the beginning of MN11 (STIUCA 2003), but could be older. Oranovo could be of similar age. CODREA (1996) noted that it apparently never crossed the Carpathians. Oranovo marks together with Staniantsi and Kromidovo (Bulgaria), Pentalophos-1 (Greece) and Marievo region (Rep. of Macedonia: a molar fragment with preserved protoloph, coll. NMNHS) the western limit of the range of Chilotherium.

The tooth from Staniantsi is the apex of the left incisor, with a black to brown-grayish color, indicating that it comes from the coal levels of the quarry. It has all the characteristics mentioned in the diagnosis of Ch. (Chilotherium). The tip of the tusk (as in the Slatino i2) has a small abrasion facet indicating that it was also perhaps used for digging; from what remains of the tooth, it looks somewhat larger than the i 2 of Ch. cf. sarmaticum from Oranovo; thus, we refer it only doubtfully to the same species.

\section{Chilotherium cf. kowalevskii PAVLOW, 1913}

Type-loc ality: Grebeniki, Ukraine, probably first half of the Turolian.

D i g n o s is : dorsal skull profile gently concave, zygomatic arch very robust, paroccipital process rather short; upper premolars large, with strong crochet, and long antecrochet connecting the metaloph, thus closing the medisinus almost up to the top of the crown; i1 shed late in life; limb bones stocky.

M a te ri a 1: FM 2700 unworn left P3 and FM 2699 right P4 (P1. 1, Fig. C); FM 2698 fragment of left mandible with m1-m3; FM 2697 incomplete mandible with left i2 and left and right p2-m2 (coll. NMNHS), coachbuilder yard, Yambol.

Des cription : besides the slight difference in L/W proportions (P3: 34.2 x 42.6; P4: $38.5 \times 45)$, the two upper teeth are remarkably alike and are certainly from the same individual. They are moderately hypsodont; the labial wall is rather flat, with only a small paracone fold which vanishes towards the base of the crown. There is a complete lingual cingulum around P3, and probably also around $\mathrm{P} 4$, but it is much higher anteriorly and posteriorly, where it closes a antero-posteriorly elongated deep post-fossette. The protoloph forms a regular curve from the paracone to the hypocone, completely closing lingually the medisinus up to the top of the crown 
on P3, whereas on P4 its lingual end (antecrochet) descends somewhat, to meet the hypocone lower down. The protocone is only apparent as a distinct entity in the lower half of the crown, a deep pinching separating it from the rest of the loph. Both teeth have strong crochet and crista, which probably met to close a medifossette after heavy wear.

The mandible FM 2697 is of a subadult specimen. It shows the broadened symphysis typical of Chilotherium. The right tusk (i2) is missing, and only about $1 / 3$ of the left one is erupted. Its cross-section is clearly triangular, with well expressed edge between the ventrolateral and ventro-medial faces. The paralophids of the cheek-teeth, including $\mathrm{p} 2$, are long, the anterior and posterior valleys are short, V-shaped. Measurements are given in Tables $2 \& 3$

The semimandible FM 2698 is from an old individual and lacks the anterior half. It has a thin corpus and relatively massive ramus, strongly developed and rounded mandibular angle, and large vascular incisure.

Comparis ons: This morphology of the upper premolars (similar to the semimolariform pattern of HEISSIG, but probably secondarily acquired) is not common in the Eastern Mediterranean, and HEISSIG took it as characteristic of Chilotherium kowalevskii, a species first described from Grebeniki by PAVLOV (1913). The mandibular teeth dimensions fit well those given by KorOTKEVICH (1970) for the type locality, Grebeniki. HeISSIG (1996) listed it also from three Anatolian localities, and from Losengrad (Kirklareli) in European Turkey, from where BAKALOV \& NIKOLOV (1962) had reported an upper molar as Aceratherium angustifrons ANDREE, 1921, a Samos species that HEISSIG (1999) considered as synonymous with Ch. kowalevskii.

Pending detailed study of the material (especially the rich collection from Çorakyerler), we will accept HEISSIG'S conception of the species, which is thus distributed along the Northern, Western and Southern parts of the peri-Pontic region.

\section{Chilotherium sp.}

Mat e ri a l: a right M3, coll. NMNHA - A1030, from Ahmatovo (P1. 1, Fig. D).

Description and comparison: The tooth is in medium wear but was probably rather hypsodont. The labial wall is vertical, rather flat and with smooth relief, with weak paracone fold. There is a strong cingulum along the base of the protoloph base, plus a weak labial cingulum at the base of the ectoloph. The crochet is strong and curved mesially, the crista is vestigial. The antecrochet is characteristic of a chilothere in being very long, with a distal part curved lingually, descending abruptly down and reaching the lingual border of the tooth, leaving a narrow deep fossette between it and the protocone. The hypocone part is missing but was separated down to the bottom of the medifossette from the antecrochet. The protoloph is regularly curved. The protocone becomes abruptly wider towards its base; it is well separated 
from the rest of the protoloph by a strong double pinching. The tooth is large: ectoloph length $=$ $54.4 \mathrm{~mm}$ (estimated restored length $\sim 56 \mathrm{~mm}$ ); width $=51 \mathrm{~mm}$. It is larger than the teeth of $C h$. sarmaticum from Berislav and of Ch. kowalevskii from Grebeniki (KOROTKEVICH 1970). By its morphology and dimensions it represents a large and evolved species; for geographical reasons, the best choice would be Ch. schlosseri, known from Samos, but a specific identification would be harsh.

\section{Genus Acerorhinus KRETZOI, 1942}

Ty p e-s p e c i e s : Acerorhinus zernowi (BORISSIAK, 1914), from Sebastopol (MN10).

D i g n o s is : post-orbital process usually small, enlarged supra-orbital process, nasal notch close to orbit, often with a strong facial crest, premolars long, upper teeth with strong crochet, lower teeth with a short paralophid. The symphysis is moderately widened; the lower incisors are large and tusk-like, with subtriangular cross-section, with smooth border between the lateral and the ventral surfaces, which are subequal in width, and with large dorsal surface, moderately enlarged towards the base, limited by sharp medial and lateral cutting edges.

\section{Acerorhinus sp.}

Materials from Bulgaria: From Kalimantsi, in the NMNHA: K-595, almost complete skull, lacking the premaxillae and most of the nasals (P1. 2, Figs. A-C); K-596, caudal part of a skull; K-600, fragment of maxilla with M2-M3; K-608, complete mandible (P1. 2, Figs. D-E); in the DGUS: complete mandible (BAKALOV \& NIKOLOV 1962, pl. 6, figs.1-2) and maxilla (BAKAlOV \& NiKOLOV 1962, pl. 5, fig.1). The mandible in the DGUS was discovered at Kalimantsi-1 (NIKOLOV 1985); all other materials are from higher levels of Kalimantsi. From an unknown locality near Slatino, called Slatino-1, in the NMNHS: fragment of maxilla (SPASSOV et al. 2006, fig.2B).

Description: On skull K-595, the nasal notch is long, reaching the level of M1, and is close to the orbit, the anterior border of which is above the middle of M2. The skull narrows rather abruptly in front of the orbits, but there is no conspicuous facial crest. The orbits are small, their dorsal rim is at the level of the skull roof, and the zygomatic root is deep. There is a long sagittal crest, and the occipital is high and inclined dorso-caudally. The cranial basis is narrow, the post-glenoid process is transversely flattened, the post-tympanic process is poorly expanded, the auditory region is cranio-caudally shortened, and the oval foramen is well-distinct from the anterior lacerated foramen. These latter features, which are also visible on K-596, are welldistinct from those observed in horned rhinos.

M e a s u r e m e n t s: length condylo-P2 = 463; length condylo-M3 = 216; length from condyle to front of glenoid surface $=125$; from condyle to front of orbit $=290$; from front of 
orbit to nasal notch $=63$; maximum supra-orbital width $=190$; bizygomatic width $=300$; maximum width over post-tympanic processes $=200$.

The teeth of K-595 are in medium wear and well-preserved (measurements: table 1). The external wall is convex on the premolars but almost flat on the molars, except for the paracone fold. The protocone is pinched, with a well-marked antecrochet, flattened lingually, and expanded on M2-M3. There is no crista, but the crochet is long on M2 and moderate on the other teeth. The cingulum is continuous lingually on the premolars, but absent on the molars. The premolar row is almost as long as the molar row. The maxilla in the DGUS, referred to Aceratherium zernowi by BAKALOV \& NIKOLOV (1962), is similar, except that the antecrochet is stronger on M2 but weaker on the premolars, not blocking the entrance to the medisinus.

The mandible K-608 (Pl. 2, Figs. D-E; measurements: table 2) has an almost straight ventral border, a ramus inclined dorso-rostrally, and an expanded goniac area. The diastema is short. The incisors are inserted not very wide apart, but the ventral border of the symphysis is concave between them. They are robust (diameters $=33.5 \times 22$ ), parallel but strongly curved upwards, with a subtriangular cross-section, with two sharp edges, facing medially and laterally, and a rounded ventro-lateral angle.

The cheek-teeth (measurements: table 3) are narrow and brachyodont, so that the crescents are shorter than in horned rhinos, but the paralophid has the same lingual extent. There is a labial cingulum on all teeth, and the premolars are rather long.

The mandible in the DGUS, which is from an older individual, displays the same features, except that the ventral border is slightly convex, the gonion less expanded, and the ascending ramus still more inclined. The incisors look thicker (diameters $=36.5 \times 35)$ because the measurements are taken at the very base of the crown, and less upright, in part because they are more worn.

The Slatino-1 maxilla has already been described by SPASSOV et al. (2006), who referred it to Aceratherium sp., but in light of the other material, it should more probably be included here. The antecrochet is well-marked, especially on the broken P4 (not figured by SPASSOV et al. 2006), the cingulum is very strong, thus resembling A. zernowi from Sebastopol.

Comparis ons: The many species that were included in this genus (see the discussion on the genus below) can be compared as follows with the Kalimantsi form.

A. zernowi (BORISSIAK, 1914), the type-species, from the late Vallesian of Sebastopol, is rather distinctive, and differs from the Kalimantsi form by its short broad skull, correlated with an occipital plane inclined dorso-cranially and a short sagittal crest. The dorsal profile is concave, the orbit is less elevated, the protocone less flattened lingually, and the crochet and antecrochet are weak on the molars, but clearly stronger on the premolars, especially on P4. On the mandible, the diastema is long, the incisors are diverging, and they are certainly less upright 
than in the upper levels of Kalimantsi. According to HeISSIG (1999), A. zernowi also occurs at Pentalophos and Kayadibi, of late Vallesian to early Turolian age,

CERDEÑO (1996b) referred to the same species a nice sample from the Middle Miocene of Tung Gur, but the skull is much narrower relative to its length, the nasals are much longer (compare BORISSIAK 1914, pl. 6, fig. 1b, and CERDEÑO 1996b, fig. 2), the orbit is much lower than the skull roof. It further differs from the Kalimantsi sample by a shallow nasal notch, and stronger mandibular symphysis and incisors. We believe that the Tung Gur form is only distantly related to Acerorhinus.

FORTELIUS et al. (2003) also referred to A. zernowi several specimens from the Vallesian of Sinap Tepe, Turkey. Our comparisons are based upon their short description and our own brief examination of some of the Sinap material in MTA, including the skull and mandible illustrated by FORTELIUS et al. (2003, fig. 12.2), and supposed by them to be lost, but which was on display in the MTA museum as late as 2001. Still, our knowledge of this important sample remains poor. The Sinap skull (MTA-1998) has an occiput which is inclined dorso-caudally, a rather shallow nasal notch and a faint facial crest, as at Kalimantsi, but the zygomatic arch is more slender; the crochet is weak and the protocone is not very flattened, but the molars of a maxilla MTA-2021 (FORTELIUS et al. 2003, fig. 12.3) have a strong crochet and a protocone which is still more flattened lingually than in most Chilotherium (it is hard to understand why FORTELIUS et al. 2003:286, wrote the opposite). A mandible from Sinap Loc. 49 (ForTELIUS et al. 2003, fig. 12.4), of late Vallesian age, shares with K-608 upturned incisors; this is certainly a difference with the Sebastopol mandible (BORISSIAK 1914, pl. 8, fig. 2), since both are male in a similar wear stage. Thus, despite the approximate contemporaneity, identification of the Sinap material with the Sebastopol species is doubtful, but it does share some similarities with the Kalimantsi fossils.

From Karaslari near Veles, a skull in the Natural History Museum, Skopje, Macedonia, also has large lower incisors curving upwards. Although they are unfortunately mostly reconstructed in plaster, it is likely that they were rather similar to the ones from the upper levels of Kalimantsi.

More recent Acerorhinus from Turkey are a skull from Kavakdere (FORTELIUS et al. 2003, fig. 12.5), a skull from Kayadibi (HeISSIG 1999, Fig. 16.11, middle figure), and some limb bones from Akkaşdağı (ANTOINE \& SARAÇ 2005). They have a concave cranial profile, and a robust zygoma, but the inflated supra-orbital process and much folded tooth pattern differ from the Kalimantsi skull.

From Chobruchi in Moldavia, a site probably close in age to Kalimantsi, PAVLOV (1914) described as Aceratherium incisivum several remains also referred to Acerorhinus by FORTELIUS et al. (2003), but the differences between them and A. incisivum from Eppelsheim (HLMD) or 
Prottes in Austria (NHMW) amount mainly to a shallower nasal notch, deeper choanae, and more convex mandibular border, and generic distinction is perhaps not warranted. The

Chobruchi material differs from the Kalimantsi sample by the same features, plus an occiput not stretched caudally, an orbit set less high in the skull, a very long post-glenoid process, a longer mandibular diastema and higher ramus (all these features make the Chobruchi rhino more like A. incisivum), and no sagittal crest (perhaps not a very significant feature, as the A. incisivum from Eppelsheim may or may not have a sagittal crest).

The skull of Acerorhinus fuguensis DENG, 2000 from the latest Miocene of China is similar to that of Kalimantsi in its occiput inclined dorso-caudally, sagittal crest, robust zygoma, moderately deep nasal notch, but the narrowing in front of the orbit is stronger, the mandibular symphysis narrower, and the teeth are well-distinct by their long crochet (closing the medifossette on the premolars) and antecrochet, and the bizarre closure of the anterior valley on the lower teeth.

Diceratherium tsaidamense BoHLIN, 1937, from the middle Miocene of China, has been referred to Acerorhinus by HEISSIG (1975), and was considered by FORTELIUS et al. (2003) as close to the Sinap Acerorhinus. The skull is high and narrow, the nasal notch very deep, the glenoid fossa high above the tooth-row, and the anterior premolars are quite small. The mandibular symphysis is rather narrow, but the mesial edges of the I2s are upturned, as in Chilotherium. These are all differences with the Kalimantsi specimens.

These rather inconsistent stratigraphic and geographic patterns of distribution of the species referred to Acerorhinus cast some doubts on the contents of the genus. The form from the late Vallesian of Sinap Loc. 49 might be close to the one from Kalimantsi-1 and Karaslari, but its referral to A. zernowi is disputable. Perhaps both samples could represent two stages of a separate lineage that could be a new species, but we refrain from naming it, pending detailed study of the Turkish material.

D i s c u s s i o n: The generic name Acerorhinus has been mostly revived by HEISSIG and co-workers (HEISSIG 1989, 1999; FORTELIUS et al. 2003). According to them, and although a diagnosis of the genus has never been provided, this lineage shares with Chilotherium the loss of upper incisors, and flattening of the lower ones, which are kept sharp by wear against the upper lip, all these characters being probably related. However, whereas the i2s of Aceratherium and Acerorhinus retain the plesiomorphic orientation and morphology of the lower tusks (dorsal occlusal surface limited by two cutting edges), derived Chilotherium present an apomorphic condition of the tusks: the occlusal surface turns latero-dorsally and the tooth retains a single very sharp cutting edge, the medial one, which shifts to a dorsal position, in relation to some changes of the function of the food-catching apparatus, presumably becoming more effective for cutting hard vegetation. The nasal notch is deeper than in Chilotherium, and thus closer to the 
orbit, and the facial crest (the caudal border of the insertion of the narial musculature) is also close to the orbital border. The antecrochet is not lengthened as in Chilotherium, but the crochet may be quite long. Acerorhinus also lacks the Chilotherium specializations of triangular i2s with much upturned mesial (medial) edges, very wide symphysis, short premolars, and elevated orbit. Still, both genera must be closely related, as shown, e.g., by Chilotherium primigenium DENG, 2006, from China, which has an Acerorhinus-like face, but a very wide symphysis.

Unfortunately, one of the basic features for the definition of Acerorhinus, the loss of upper incisors, has not been definitely established for any of the species included in the genus, as no specimen has the premaxillae well-preserved. Lack of upper incisors is likely because the strong facial crest, caudal limit of the origin of the maxillo-labialis muscle, suggests that the latter, hence the upper lip, were quite powerful. Detailed examination of the lower incisors might tell whether they would wear against another tooth or against food and upper lip; but such a study remains to be done. However, in rhinos in which i2 wears against a well-developed I1, such as the modern Rhinoceros or Aprotodon borissiaki, there is a double attrition facet on i2, the lingual part being slightly concave. Such a distinction cannot be seen on the Acerorhinus i2s observed by us, probably showing the lack of the corresponding I1, or at least its very reduced size and function.

Still, the distinction from Aceratherium is often difficult, as the type-species A. incisivum from the Vallesian of Central Europe; also has, e.g., a deep nasal notch, abruptly narrowing nasals, a low orbit, large premolars, and incisors that are not more rounded than in some species of Acerorhinus. In spite of this, we agree with HeISSIG (1989, 1999), ForTELIUS et al. (2003), and GIAOURTSAKIS (2003) that there existed in the upper Miocene of South-Eastern Europe some rhinos matching their conception of Acerorhinus, but which were often named Aceratherium incisivum by local authors (BAKALOV \& NiKOLOV 1962; NiKOLOV 1985; KOROTKEVICH 1988).

Genus Brachypotherium ROGER, 1904

Ty p e-s p e c i s : Rhinoceros goldfussi KAUP, 1834, from Eppelsheim (MN9). Brachypotherium sp.

Material: A-599, anterior part of a skull, broken behind the orbits, and lacking the nasals; the whole bone surface is badly damaged, and the labial part of the ectoloph is missing on all teeth, except a small piece on the right M1 (P1. 1, Fig. F); A-620, P4 (P1. 1, Fig. E); A-1031, 1032 right and left $\mathrm{P} 2 \mathrm{~s}$ and A-1033 right M3, all three teeth probably from the same individual. All these specimens are from Ahmatovo in NMNHA. There is also an unnumbered incomplete juvenile skull from Kalimantsi in DGUS, referred to Dicerorhinus schleiermacheri by BAKALOV \& NiKOLOV (1962), which formed the basis of the inclusion of the latter species in the faunal list of Kalimantsi 3-4 (Turolian fauna) by NIKOLOV (1985). 
Description: The skull fragment A-599 is very large, close to the maximum size of the horned rhinos (Ceratotherium, Dihoplus and elasmotheres) of the Late Miocene. However, the orbit is not much lower than the cranial roof, the nasal notch is deep (bottom above the rear of P4) and very close to the infra-orbital foramen: these features point unambiguously to a "hornless" rhino. In the Late Miocene, most members of this informal group (Aceratherium, Acerorhinus and related forms, Chilotherium; some of them bearing in fact small horns) are much smaller than A-599, only Brachypotherium being comparable in size. Several other features support an assignment to the latter genus. The cranial roof is distinctly convex, not flat or even depressed as it is in the other hornless genera; the palate is broad; the premolars are much shorter than the molars, broad relative to their width, and the remaining fragment of the ectoloph on M1 unambiguously shows that this tooth was very brachyodont; the teeth have no crista, and the crochet is weak, although it is bifid on M2; the protocone and hypocone are only slightly pinched on the molars, and the antecrochet is weak. The cingulum is quite reduced, as it is also often in African forms and in B. perimense (cf. HEISSIG 1972, pl. 10, fig. 9), but this contrasts with most European teeth referred to Brachypotherium.

Measurements of A-599: width over M2s $=245$; bizygomatic width $=330+$; from orbit to nasal notch $=104$. Estimated L x W of M2 (maximum) $=65 \times 73$. Estimated L x W of P4 $=46.5 \mathrm{x}$ 67.5 .

These measurements are close to those recorded by HOOIJER \& PATTERSON (1972) for B. goldfussi from Eppelsheim, but it should be noted that they are significantly larger than those given by RoGER (1900) for the same population (e.g., P4 = 37 x 57; M2 = 49 x 56).

An isolated P4 A-620 is also very brachyodont (P1. 1, Fig. E), and large (L x W = 52.6 x 63.1).

In spite of the strong wear, the convergent walls of teeth A-1031-1033 show that they were brachyodont. On the premolars, the labial wall is oblique and rounded, curving mesiolingually; the lingual cingulum is well marked; there is a minute crochet and no crista; the protoloph is narrow but the protocone is large. The M3 also has weak external relief, rudimentary antecrochet and with arched external wall. The vestige of the metastyle, resting on the base of this wall, gives the basal outline a trapezoidal shape.

Measurements: P2: A-1031: L x W =37 x 46; P2: A-1032: L x W 34,5 x 45.7; M3: A1033: $\mathrm{L}$ x W $=53.3$ x 49.5.

A juvenile skull from Kalimantsi in the DGUS, lacking the occipital, and with the nasal region reconstructed in plaster, was figured by BAKALOV \& NIKOLOV (1962, pl. 9 and pl. 10, fig. 3) as Dicerorhinus schleiermacheri. It clearly belongs to a hornless rhino, as shown by the upper orbital border reaching the level of the skull roof, slightly inflated supra-orbital area, deep nasal notch, reaching the level of DP3 and almost incorporating the infra-orbital foramen, and 
extremely robust rostral root of the zygomatic arch. On the milk premolars, the crochet increases in length from DP2 to DP4, there is a weak crista, the protocone is pinched but not flattened lingually, the labial wall has a well-marked paracone fold and a weaker metacone fold, and the cingulum is restricted to the mesial side. They are about as broad as they are long, much larger than in other hornless rhinos, and even larger than all Late Miocene Ceratotherium milk teeth that we have seen.

Compari s on s: Brachypotherium had long been considered as a long-lasting genus, but HeISSIg (1999) referred the early middle Miocene forms to Prosantorhinus, thus restricting Brachypotherium to zones MN6 to MN9 (although ForTELIUS et al. 2003, extend its range to MN5). To our knowledge, there is only one secure mention in the European Turolian, at Eichkogel in Austria, well-dated to MN11 by rodents (DAXNER-HöCK 1996), from where VACEK (1900) illustrated typical Brachypotherium lower molar and upper teeth. The genus is still present in the latest Miocene of both North and East Africa (HARRIS \& LEAKEY 2003, and references therein), but the Bulgarian finds are the latest representatives of the genus in Europe. Two explanations can be offered for this late occurrence. Either, Bulgaria could have acted as a refuge for this genus. Another alternative hypothesis is that of a middle Turolian penetration(s) of Brachypotherium in Bulgaria from Africa via Asia Minor. A trilophodont gomphothere presumably from deposits near Seltsi (very close to Ahmatovo and probably close in age) was referred with caution to Gomphotherium angustidens by MARKOV (in press) who notes that a trilophodont gomphothere is also present in the Upper Nawata (Lothagam, Kenya; TASSY 2003), broadly contemporaneous with the fossiliferous area along Cherkezitsa area, and hypothesizes on possible faunal exchanges between East Africa and the Balkans in the latest Miocene.

Rhinocerotinae GRAY, 1821

Genus Dihoplus BRANDT, 1878

Ty p e-s p e c i e s : Rhinoceros schleiermacheri KAUP, 1832, from Eppelsheim, MN9.

Diagn o sis: A two-horned rhino. Tooth row rather caudal, nasal notch above anterior premolars. Cranial basis short, post-glenoid apophysis close to the paroccipital process. No P1. Upper premolars primitive, submolariform. Molars with vestigial antecrochet, crista weak, missing on DP3-DP4. Lower i2 present.

\section{Dihoplus cf. schleiermacheri (KAUP, 1832)}

Type locality: Eppelsheim, MN9.

Diagn os is: Nasal notch reaches only the anterior border of P2; temporal lines closely approaching; zygomatic arch robust; paroccipital process long. Upper I1 rather large and functional, I2 and i1 present, i2 very large. 
Materia1: a skull fragment with well-worn right P2-M2, lacking molar ectolophs, from an unknown locality near Slatino, called Slatino-2.

This specimen, already described by SPASSOV et al. (2006), was referred to this species rather than to D. pikermiensis because of the position of the nasal notch. As discussed by these authors, this find suggests the occurrence of a Vallesian fauna near Slatino, as the record of D. schleiermacheri in the Turolian (including reports by BAKALOV \& NIKOLOV 1962, and NIKOLOV 1985) is certainly due to its tooth similarities with $D$. pikermiensis as well as to a kind of traditional "inertia" to refer all Late Miocene "Dicerorhinus" s.1. to this species. It also occurs at Yulaflı in European Turkey (KAYA \& HEISSIG 2001), but the site is in fact clearly Vallesian (GERAADS et al. 2005b).

\section{Dihoplus pikermiensis (TOULA, 1906)}

Type-1ocality: Pikermi

Diag n o s is: Nasal notch more caudal than in the type-species, with an oblique ventral border. No sagittal crest. I2 absent, I1 vestigial, i2 reduced.

Materi a1: From Strumyani: FM-2469: crushed but virtually complete skull (Text-fig. 2; Pl. 1, Figs. G-H); FM-2470 (coll. NMNHS): complete mandible, found close to the skull and almost certainly of the same individual (P1. 1, Fig. I-J). From Hadjidimovo: HD-597: incomplete juvenile skull; HD-598: incomplete skull of old adult (P1. 3, Fig. C); HD-605: maxilla of an old adult; HD-606: upper tooth-row; HD-607: juvenile maxilla (Pl. 3, Fig. D); HD-616: juvenile mandible; HD-697: juvenile maxilla; HD-671 to HD-674: upper premolars; HD-615: complete mandible (Pl. 3, Figs. E-F); some metapodials listed with their measurements table 6. From Kalimantsi: K-601, K-602, K-604: incomplete sets of upper milk teeth (coll. NMNHA).

Description: The skull from Strumyani is complete, but unfortunately crushed, and the very friable bone made it difficult to prepare. Still, its most important features are clearly visible (Text-fig. 2). It carried two horns, on the frontals and nasals. The nasals are long and form a gentle curve. The premaxillae, rarely preserved in fossil forms, are here intact; they are rectangular, about $60 \mathrm{~mm}$ long before $\mathrm{P} 2$, and show no trace of an incisor alveolus. The anterior orbital border is above M2-M3; the lower floor is not slanting ventrally. The occipital crest overhangs the condyles, but the outline of the occipital face is deformed. The cranial basis is shortened, and the post-tympanic process comes into contact with the post-glenoid process, although without fusion, but closing ventrally the aural foramen (P1. 1, Fig. G). The cheek-teeth (P1. 1, Fig. H) are much worn, but there is a weak metacone fold on P4, the spurs in the medisinus of the molars are rather weak, and the protocone tends to be isolated from the protoloph by vertical furrows. All these features of the skull and teeth point to Dihoplus pikermiensis rather than to Ceratotherium neumayri, the other two-horned rhino of the Eastern 
Mediterranean Late Miocene (GERAADS 1988; GIAOURTSAKIS 2003; GIAOURTSAKIS et al. 2006). Measurements are given in tables 1 and 4.

The adult skull HD-598 is broken behind the orbits and in front of P2. The nasals are quite long and somewhat splayed out anteriorly, and the area of insertion of the posterior horn is rugose, but the upper profile is almost straight. The nasal notch is deep; its bottom is above the middle of P4. The front of the orbit is above the back of M2. The zygomatic arch is deep and robust; the inferior orbital border is not slanting ventrally. The choanae reach the anterior border of M2. The teeth are much worn (P1. 3, Fig. C). The paracone rib is well marked; the hypocone is connected to the ectoloph by a narrow metaloph bridge. At this wear stage, on the molars, there is no visible crista, the crochet is weak, and on the premolars the lingual tubercles are connected. The protocone is clearly pinched on the molars, and has a small basal cingulum on P3-M3. A few more molars and premolars display the same features. An unnumbered occipital has an almost straight nuchal crest that is narrower than the base of the occipital face, which has an almost straight lateral profile.

The mandible from Strumyani, FM-2470, probably associated with skull FM-2469, has both sides well preserved except for the ramus, and the symphysis is complete. It narrows abruptly in front of $\mathrm{p} 2$, but is rather long. There is no i1, but a pair of $\mathrm{i} 2 \mathrm{~s}$ of unexpectedly large size (transverse diameter $=26 \mathrm{~mm}$, dorso-ventral diameter $=21 \mathrm{~mm})$. Like the cheek-teeth, they are much worn, and much cracked, so that the precise outline of the crown is hard to reconstruct, but the section was rather oval. The i2 occlusion facet is large, dorso-caudally and somewhat medially oriented and occupies all the width of the tip of the tooth. The ventral border of the mandibular corpus is straight.

HD-615 (P1. 3, Figs. E-F) is a complete lower jaw with both sides well preserved. The depth of the corpus decreases regularly towards the front, with an almost straight lower border. The symphyseal region is similar to that of the Strumyani mandible. Only one non-functional and unworn, vestigial incisor is present on the right side. It is a minute peg-like tooth, inserted far away from the midline, and thus certainly a di 2 or i 2 rather than a di1. Although the median part of the symphysis is not perfectly preserved, it is almost certain than there was no dil or i1. Measurements of the mandibles are given in tables 2 and 3.

Incisors, both deciduous and permanent, are absent in modern Ceratotherium, but they may be present in Diceros bicornis (SCHAURTE 1966, and our observations), where they are minute, and almost certainly deciduous. Among the fossils, they are lacking in C. neumayri (BMNH M4399; SMF 13260; MGML S1060, all from Samos; also ForTELIUS et al 2003; GIAOURTSAKIS et al. 2006), but they seem to be normally present in Dihoplus. They are quite strong in the vallesian D. schleiermacheri, but reduced in D. pikermiensis. 
The occurrence of upper incisors in D. pikermiensis is demonstrated by an unpublished skull from Pikermi in the NHMW, definitely of this species, with well-worn cheek-teeth, and which has well preserved long premaxillae bearing small incisors. According to GIAOURTSAKIS et al. (2006), a similar skull is preserved in the University of Athens.

Lower incisors are more common. Very small ones are present on two mandibles from Pikermi (MNHN N 958; BMNH M10150), but GIAOURTSAKIS et al. (2006) noted that the alveoli are larger on another specimen from Pikermi (IPUW $\mathrm{N}^{\circ} 342 \mathrm{red}$ ) and on a mandible from Kerassia, a locality close in space, and probably also in age, to Pikermi. Quite logically; they attributed these differences to sexual dimorphism. However, although these authors provided no measurement of the empty alveoli, they appear from their figure smaller than at Strumyani (GIAOURTSAKIS et al. 2006, fig.3C; the scale is certainly incorrect but the maximum width of the symphysis is given as $76.3 \mathrm{~mm}$ ). Two associated skulls and mandibles from Karaslari and Bashibos in the Natural History Museum, Skopje, Macedonia, also have no upper incisors but relatively large lower incisors, albeit smaller than at Strumyani.

HD-597 preserves the same part of the skull as HD-598, but from a juvenile individual. There is a clear contact between the lachrymal and nasal bones. The deciduous premolars are only slightly longer than broad, they have no crista, DP1 has a long metaloph, and DP2 has a postfossette. Both upper tooth-rows HD-607 (P1.3, Fig.D) and HD-637/697 display the same features that are similar to those found in D. pikermiensis from Pikermi (GERAADS 1988). Some upper milk-teeth suggest that this species occurred at Kalimantsi as well. The rather wide postfossette on DP2, pinched protocone and incipient ante-crochet, are features that fit better this species than Ceratotherium, but the weak metacone fold, and presence of crista on some DP3s suggest the reverse identification; as most of these milk teeth are poorly preserved, their identifications are not definite. Measurements of the deciduous teeth are given in table 5.

On the mandible HD-616, the metalophid of dp3 has a posterior flange, which blocks lingually the posterior valley, and dp4 has a hint of anterior third lobe.

A number of post-cranial bones are preserved in the NMNHA, the best sample being that of the metapodials (measurements: table 6). They are slightly larger than in the living C. simum and than in the sample from Pikermi, which certainly includes both $C$. neumayri and D. pikermiensis. At present, there is no definite evidence that more than one species is present at Hadjidimovo, although the range of variation for some measurements is large (table 6), and we provisionally assign them all to $D$. pikermiensis, pending publication of the distinctive criteria (GIAOURTSAKIS, in prep.).

Comparis on s: This species had often been confused with Ceratotherium neumayri, with which it co-exists at Pikermi and in other sites, but GERAADS (1988) showed that they are well distinct, and GIAOURTSAKIS (pers. comm.) greatly increased the number of post-cranial 
distinctive features. Its generic affinities are debatable. FORTELIUS et al. (2003) included it in Stephanorhinus, but the plio-pleistocene forms of this genus (type-species: S. etruscus) share at least two synapomorphies, loss of upper incisors and an ossified nasal septum, that are definitely not found in D. pikermiensis, and we feel it better to restrict this generic name to these welldefined Plio-Pleistocene forms. Instead, we will follow GIAOURTSAKIS (2003) and GIAOURTSAKIS et al. (2006) who link Dihoplus pikermiensis with D. schleiermacheri; they share a similar cranial and dental morphology, the main difference being the sharp reduction in incisor size in the Turolian form. The large size of the Strumyani incisors speaks in favour of an earlier age for this locality, and lends some support to the derivation of D. pikermiensis from D. schleiermacheri.

Tribe Dicerotini RINGSTRÖM, 1924

Genus Ceratotherium GRAY, 1868

Ty p e-s pe c i es: Ceratotherium simum (BURCHELL, 1817), living white African rhino.

D i a g n o s is: Nasal and frontal horns. Nasal bones rounded and short, not contacting the lachrymal. Lower border of orbit slopes downwards. Weak post-orbital process. Broad nuchal crest. Premaxilla much reduced. Upper and lower incisors at most vestigial, usually absent. Paracone fold weak. Antecrochet absent (GERAADS 2005).

\section{Ceratotherium neumayri (OSBORN, 1900)}

Type-locality: Maragha

D i a g n o s i s: GERAADS (2005) considered this species as a stem-form from which both later Ceratotherium and Diceros arose, thus having no apomorphic features. Furthermore, the species is currently being revised by I. GIAOURTSAKIS, and we will provide no diagnosis.

Mater i a 1: From Kalimantsi: K-594: well-preserved skull of a young adult, lacking only the nasals and the part anterior to P2 (P1. 3, Figs. A-B). K-593: a juvenile maxilla with DP1DP4 (coll. NMNHA); from Strumyani: complete mandible FM-2468 (coll. NMNHS).

De s c ription: Skull K-594 (Pl. 3, Fig. A) is somewhat crushed dorso-ventrally, but its shape and proportions are quite clear. The dorsal profile is slightly concave. The nuchal crest largely overhangs the condyles, and is deeply notched medially. The skull is slightly broader at this level than over the post-tympanic processes. The impact of crushing on the morphology of this area is certainly weak. The bottom of the nasal notch is above the anterior border of P3, the infra-orbital foramen is above the anterior third of $\mathrm{P} 4$, and the anterior border of the orbit above the anterior border of M2. All these positions are quite close to the average for C. neumayri (see GERAADS 2005, fig.6). The lower orbital border is inclined ventro-laterally, the zygomatic arch is long and slender, and the lower pterygoid border strongly oblique. The cranial basis is rather 
long, and the paroccipital process is well behind the post-glenoid process. Measurements are given in table 7.

The teeth (Pl. 3, Fig. B) are hypsodont, the ectoloph is sinuous but the paracone fold is weak. All teeth have a crochet and a small crista, the protoloph and metaloph are of regular thickness, and not pinched. The cingulum is continuous around the lingual side of the premolars.

All these features allow the distinction from Dihoplus pikermiensis, but are identical to those of C. neumayri from Pikermi and other eastern Mediterranean sites (GERAADS 1988, 1994), which is a likely ancestor for both modern African species (GERAADS 2005). They definitely show that this ancestor was more like the living "white" rhino than like the more browser Diceros in cranial morphology, and probably in ecology too.

K-593 is a juvenile maxilla with DP1-DP4 that can unambiguously be referred to the same species, rather than to D. pikermiensis, thanks to the criteria put forward by GERAADS (1988) and GIAOURTSAKIS et al. (2006): DP3 and DP4 are longer than broad; there is a strong crista, and no postfossette on DP2. Another, poorly preserved set of upper milk-teeth, K-603, is perhaps of the same species. Measurements of the milk-teeth are given in table 5 .

The Strumyani mandible FM-2468 lacks the right ramus, the left one is damaged. It is not very large, but robust, with deep and strongly convex corpus. The symphysis is somewhat damaged on the right side but it is clear that it is short and very broad, without any trace of incisors. All these mandibular features, also present on a newly discovered (2007) mandible from the same locality, are well distinct from those of Dihoplus. The cheek-teeth are rather worn. The molar paralophids are long, better developed for example from the ones of the Dihoplus mandible from the same locality, which are in the same stage of wear. Measurements are given in table 2 .

Two metapodials, a McII K-629 and an unnumbered McIV, are about as long as the shorter specimens from Hadjidimovo. The McII has a short magnum facet, and a palmar tubercle, like the specimens from Pikermi referred to this species (GERAADS 1988).

Ceratotherium neumayri is a common rhino of the Eastern Mediterranean Late Miocene. It has a good record in Pikermi, Samos, and as far East as the Caucasus and Maragha, and has been reported from a number of other sites in Greece and Turkey. Strumyani is its northernmost definite record. The range of this species probably matches that of open savannahs in the Turolian; we may tentatively suggest that its occurrence in the late Vallesian of Pentalophos (GERAADS and KoufOS 1990) and Sinap (FORTELIUS et al. 2003) is linked with the precocious opening of the landscapes in this area.

It probably is the ancestor of both living African forms (GERAADS 1988; 2005); GERAADS \& Koufos (1990) failed to recognize any evolutionary trend during the Late Miocene, but it is possible that its size increased towards the end of the Turolian (ANTOINE \& SARAÇ 2005). 


\section{Conclusions}

These new or revised Bulgarian finds greatly improve our knowledge on the Late Miocene Rhinos of the Balkan-Iranian zoogeographic province in several aspects:

\section{Morphology and taxonomy.}

The morpho-functional importance of the chilothere tusks is reiterated, as these teeth have major taxonomic and ecological significance. The existence of forms with plesiomorphic features of i2, mandible, cheek-teeth and cranial features prompts us to separate them in a new subgenus Chilotherium (Eochilotherium). Chilotherium (Chilotherium) presents apomorphic features in the tusks. After the loss of I1, the dorsal (occlusal) surface turns latero-dorsally and the tooth retains only the very sharp (by attrition with the upper lip), sickle-like, medial cutting edge, which turns dorsally, presumably more effective for cutting hard vegetation, in relation to some change of the function of the food-catching apparatus and feeding behaviour. The species Chilotherium sarmaticum, mostly discussed in the Russian literature, but not in recent taxonomic and faunal analyses, should probably be considered as valid, thus representing the earliest true chilothere.

Acerorhinus retains the plesiomorphic orientation and morphology of the lower tusks: occlusal surface dorso-medially oriented, limited by two functional cutting edges, lateral and medial. Two groups can perhaps be distinguished within this taxon: an early one (Vallesian to ?early Turolian), with broad and forwardly inclined i2, and a more progressive one, with increasingly upright tusks, that reaches at least the middle Turolian.

The discovery of a Dihoplus pikermiensis with large tusk-like i2s (Strumyani) is a strong argument supporting the gradual reduction of these teeth during the Turolian evolution of the genus.

\section{Biochronology}

The find of Chilotherium cf. sarmaticum in the Slatino genetic lithocomplex, positioned below the Strumyani lithocomplex with Turolian fauna, confirms that this is the earliest true chilothere, living most probably at the Vallesian-Turolian boundary.

The discovery of Brachypotherium in Ahmatovo and Kalimantsi extends the vertical distribution of the genus in Europe, showing it to be present until the middle Turolian in the southwestern part of the continent.

The strong i2s of the Dihoplus pikermiensis mandible from Strumyani, the largest known in this species, supports the pre-Pikermian (early Turolian?) age of this locality.

\section{Ecology}

On the basis of the skeletal morphology, especially the shortened metapodials, Chilotherium has sometimes been interpreted as a swamp or marsh dweller (e.g., BELIAEVA 
1954), but RINGSTRÖM (1924) merely regarded it as suid-like, and in fact nothing suggests aquatic habits. Its specialized food catching apparatus made it well-adapted to the vast open landscapes of the central Asiatic province (GERAADS et al. 2002).

Brachypotherium has a still more shortened zeugopod, and is often depicted with an hippopotamus-like habitus. However, the stylopod is long (CERDEÑo 1996a; HeISSIG 1999; GERAADS \& SARAÇ 2003), as in graviportal tetrapods, and the brachyodont teeth are also unexpected in a river or swamp dweller (those of modern hippos, or reduncines among bovids, are relatively high-crowned). HEISSIG (2004:253) supposed that it preferred "dryer woodland or maybe solid soil"; this is likely but its low-crowned teeth imply that it must have fed upon some soft plants.

The coexistence of Ceratotherium neumayri and Dihoplus pikermiensis at Samos, Pikermi, Kerassia, has been discussed recently (GIAOURTSAKIS et al. 2006); Strumyani-2 shows that they may be closely associated, because they were found at the same spot. As noted by several authors (HEISSIG 1999; GIAOURTSAKIS et al. 2006) Dihoplus pikermiensis could be a true browser and C. neumayri, although not a strict grazer as $C$. simum, had adaptations to tough low-level vegetation, such as lengthened skull, lack of incisors, and greater convexity of the mandible probably related to increased pressure on the cheek-teeth. Both species probably exploited different food niches in the same "Pikermian biome" of the Balkan Turolian (SPASSOV et al. 2006, and references therein).

The presence of Ceratotherium in the fossil material from the middle Turolian localities of Kalimantsi and the absence of this genus in the huge collection from Hadjidimovo is an indication of the more open conditions in Kalimantsi, in agreement with other data (MERCERON et al. 2006) and possibly reflects the gradual aridification of Southwestern Bulgaria with time.

\section{Zoogeography}

The new data refines the western boundary of the genus Chilotherium, at the same time confirming its occurrence in the Balkans (Fig. 3). The discovery of Brachypotherium could also have important biogeographic implications, if it could be demonstrated that this genus is an African immigrant rather than a Middle Miocene survivor; at present, it is hard to chose, as there is neither any representative of this genus in the upper Miocene of Greece or Turkey, arguing against a migration, nor any report in the Late Miocene of Bulgaria, arguing against a survival.

It may be expected that ongoing rhino studies in the Aegean-Pontic region will greatly improve our understanding of the Late Miocene radiation and diversification patterns in this difficult group, where mostly uniform skull and tooth patterns, and more generally scarce apomorphies (HEISSIG 1981) and frequency of parallelism hinder phylogenetic reconstruction. 
We thank M. Bertling (PIUM), J. Cuisin, F. Renoult, C. Sagne, and P. Tassy (MNHNP), B. Engesser (NHB), R. Garevski and S. Petkovski (MMNH), E. P. J. Heizmann (SMNS), M. Ivanov (DGUS), M. LeakeY and E. Mbua (KNM, Nairobi), R. Marchant (MGML), and M. YILMA (NME) for giving access to collections in their care. Many thanks also to K. HEISSIG for his comments on the manuscript. The LEAKEY FOUNDATION is gratefully acknowledged for a Grant to N. S. 


\section{Literature Cited}

Antoine, P.-O. \& SARAÇ, G. (2005): Rhinocerotidae (Mammalia, Perissodactyla) from the late Miocene of Akkaşdağı, Turkey. - Geodiversitas, 27(4): 601-632.

BAKALOV P. (1933). Funde von Hipparionenfauna bei Kalimanzi und Kromidovo, Kreis Sweti

Wrach, Sudwest Bulgarien. - Zeitschrift der Bulgarischen Geologischen Gesellschaft.

Sofia, 5(3): 257-260 (in Bulgarian, German summary).

BAKALOv P. (1939). Die Hipparionenfauna von Kalimanci und Kromidovo, Bezirk Sveti Vrać, SW Bulgarien. - Geologica Balcanica, 3(2): 82-88 (in Bulgarian).

Bakalov, P. \& Nikolov, I. (1962). Les Fossiles de Bulgarie. X. Mammifères Tertiaires. -

Académie des Sciences de Bulgarie, Sofia, 162 pp. (in Bulgarian, with French and

Russian summaries).

Beliaeva E. (1954): New materials on the Tertiary rhinos of Kazakhstan. Tertiary mammals. -

Publ. House of the Acad. Sci. of URSS. Moscow, 47 (2): 24-54.

Bohlin, B. (1937): Eine tertiäre Säugetier-Fauna aus Tsaidam. - Palaeontologia Sinica, C, 14(1): $1-111$.

Borissiak, A. (1914): Mammifères fossiles de Sébastopol. - Mém. Comité géol. NS 87: 105154.

BRANDT, J. F. (1878): Tentamen synopseos Rhinocerotidum vivientum et fossilium. - Mém.

Acad. Impér. Sc. Saint- Petersbourg, ser. 7, 26(5): 1-66.

CERDEÑO, E. (1996a): Prosantorhinus, the small teleoceratine Rhinocerotid from the Miocene of Western Europe. - Géobios, 29: 111-124.

CERDEÑO, E. (1996b): Rhinocerotidae from the Middle Miocene of the Tung-Gur Formation, Inner Mongolia. - Amer. Mus. Novit., 3184: 1-43.

Cifelli R. L. \& Kielan-JaVOROWSKa Z. (2005): Diagnosis: Differing interpretations of the ICZN. Acta Paleont. Polon., 50(3): 650-652.

CODREA V. (1996): Miocene rhinoceroses of Romania: an overview. - Acta zool. cracov., 39(1): 83-88.

DAXNER-HÖcK, G. (1996): Faunenwandel im Obermiozän und Korrelation der MN "Zonen" mit den Biozonen des Pannons der Zentralen Paratethys. - Beitr. Paläont., 21: 1-9.

De Bruijn, H., DaAms, R., Daxner-Hock, G., Fahlbusch, V., Ginsburg, L., Mein, P., MoRALES J. ( 1992): Report of the RCMNS working group on fossil mammals, Reisenburg 1990. - Newsletters on Stratigraphy 26(2/3): 65-118.

Deng, T. (2000): A new species of Acerorhinus (Perissodactyla, Rhinocerotidae) from the late Miocene in Fugu, Shaanxi, China. - Vert. PalAsiatica, 38(3): 203-217.

DENG, T. (2006): A primitive species of Chilotherium (Perissodactyla, Rhinocerotidae) from the Late Miocene of he Linxia basin (Gansu, China). - Cainozoic Research, 5: 93-102. 
Dragomanov, L., Kazarinov, V., Kojumdgieva, E., Nikolov, I., Enćev, E., Hristov. H.

(1981): Paléogéographie du Néogène des arrondissements de Pazardgik. - Palaeontology, Stratigraphy and Lithology, 14: 65-75.

Fortelius, M., Heissig, K., SARAÇ, G. and Sen, S. (2003): Rhinocerotidae (Perissodactyla). - In:

Fortelius, E., Kappelmann, J., Sen; S. And Bernor, R. (Eds): Geology and

Paleontology of the Miocene Sinap Formation, Turkey. - pp. 282-307, Columbia

University Press, New York.

GERAADS, D. (1988): Révision des Rhinocerotidae (Mammalia) du Turolien de Pikermi.

Comparaison avec les formes voisines. - Annls Paléont. 74: 13-41.

GerAads, D. (1994): Les gisements de Mammifères du Miocène supérieur de Kemiklitepe,

Turquie: 4: Rhinocerotidae. - Bull. Mus. Nat. Hist. Nat., 4ème sér., C, 16: 81-95.

GERAADS, D. (2005). Pliocene Rhinocerotidae (Mammalia) from Hadar and Dikika (Lower

Awash, Ethiopia), and a revision of the origin of modern African rhinos. - J. Vertebr.

Paleont., 25(2): 451-461.

GeraAdS, D. \& Koufos, G. (1990): Upper Miocene Rhinocerotidae (Mammalia) from

Pentalophos-1, Macedonia, Greece. - Palaeontographica 210: 151-168.

GERAADS, D. \& SARAÇ, G. (2003): Rhinocerotidae from the Middle Miocene Hominoid locality of Çandır (Turkey). Cour.Forsch.-Inst. Senckenberg 240: 217-231.

GeraAds D., GÜleç E. \& KAYA T. (2002): Sinotragus (Bovidae, Mammalia) from Turkey and the late Miocene Middle Asiatic Province. - Neues Jhb. Geol. Paläont. Monatsh., 2002 (8): 477-489.

GERAADS, D., KAYA, T. \& MAYDA, S. (2005a): Late Miocene large mammals from Yulafl1, Thrace region, Turkey, and their biogeographic implications. - Acta Palaeont. Polon., 50(3): 523-544.

Geraads D., Spassov, N. \& Kovachev, D. (2001): New Chalicotheriidae (Perissodactyla, Mammalia) from the Late Miocene of Bulgaria. - J. Vert. Paleont., 21(3): 296-606.

Geraads D., Spassov, N. \& Kovachev, D. (2003): Palaeoreas lindermayeri (WaGner, 1848) from the upper Miocene of Bulgaria, and a revision of the species. - Geodiversitas 25(2): 405-415.

GeraAds, D., Spassov, N. \& KovacheV, D. (2005b): Giraffidae (Artiodactyla, Mammalia) from the late Miocene of Kalimantsi and Hadjidimovo, South-Western Bulgaria. - Geologica Balcanica, 35(1-2): 11-18.

Geraads, D., Spassov, N. \& Kovachev, D. (2006): A new Sporadotragus (Bovidae, Mammalia) from the late Miocene of Bulgaria. - Riv. Ital. Paleont. Strat., 112(3): 473479. 
GIAOURTSAKIS, I. (2003): Late Neogene Rhinocerotidae of Greece: distribution, diversity and stratigraphical range. - Deinsea 10: 235-253.

GiaOuRtsakis, I. \& Heissig, K. (2004): On the nomenclatural status of Aceratherium incisivum (Rhinocerotidae, Mammalia). - Proc. $5^{\text {th }}$ Int. Symposium on Eastern Mediterranean Geology Thessaloniki, Greece, 14-20 April 2004, p. 314-317.

Giaourtsakis, I., Theodorou, G., Roussiakis, S., Athanassiou, A. \& Iliopoulos, G. (2006): Late Miocene rhinoceroses (Rhinocerotinae, Mammalia) from Kerassia (Euboea, Greece). - N. Jhb. Geol. Paläont., Abh., 239(3): 367-398.

GRAY, J. E. (1821): On the natural arrangement of vertebrose animals. - London Medical Repository 15: 296-310.

GuERIN, C. (1980): Les Rhinocéros (Mammalia, Perissodactyla) du Miocène terminal au Pléistocène supérieur en Europe occidentale. Comparaison avec les espèces actuelles. Doc. Lab. Géol. Fac. Sci. Lyon 79:1-1185.

HARRIS, J. M. \& LEAKEY, M. G. (2003): Lothagam Rhinocerotidae. - In: LEAKEY, M. G. \& HARRIS, J. M. (Eds.): Lothagam - The dawn of Humanity in Eastern Africa.- pp. 371385, Columbia Univ. Press, New York.

HeIssig, K. (1972): Die obermiozäne Fossil-Lagerstätte Sandelzhausen. 5. Rhinocerotidae (Mammalia), Systematik und Okologie. - Mitt. Bayer. Staatsslg. Paläont. hist. Geol., 12: 57-81.

HeISSIG, K. (1975): Rhinocerotidae aus dem Jungtertiär Anatoliens. - Geol. Jb., 15: 145-151.

HEISSIG, K. (1981): Probleme bei der cladistischen Analyse einer Gruppe mit wenigen eindeutigen Apomorphien : Rhinocerotidae. - Pal. Zeitschr., 55: 117-123.

Heissig, K. (1989): Rhinocerotidae. - In: Prothero, D.R. \& ScHOCH, R. M. (Eds.): The evolution of Perissodactyls. - pp. 399-417, Oxford Univ. Press, New York.

HEISSIG, K. (1996): The stratigraphical range of fossil rhinoceroses in the late Neogene of Europe and the Eastern Mediterranean. - In: Bernor, R., FAHLBUSCH, V., \& H.-W. MitTMANN (Eds.): The evolution of western Eurasian Neogene mammal faunas. -p.339347, Columbia University Press, New York.

HeIssig, K. (1999): Family Rhinocerotidae. - In: Rössner, G. \& HeIssig, K. (Eds.): The Miocene Land Mammals of Europe. - pp. 175-188, Friedrich Pfeil, München.

Hooijer, D. A. \& PAtTerson, B. (1972): Rhinoceroses from the Pliocene of Northwestern Kenya. - Bull. Mus. Comp. Zool., 144: 1-26.

Hristova, L., Kovachev, D. \& Spassov, N. (2002a): Hipparion brachypus Hensel, 1862 from Hadjidimovo, Southwestern Bulgaria (Late Miocene). - Comptes rendus Acad. bulg. Sci., 56(2): 77-84. 
Hristova, L., Kovachev, D. \& Spassov, N. (2002b): The Hipparions (Equidae, Mammalia) from the Upper Miocene locality Hadjidimovo, SW Bulgaria. - Review of the Bulgarian Geological Society, 63(1-3): 89-98.

Hristova, L. \& Kovachev, D. (2005): Notes on the Taxonomy of the Middle Turolian

Hipparions from the Localities near Kalimantsi Village. Proceedings of the International Scientific conference (8-11.06.2005). Faculty of Mathematics and natural sciences.

South-Western University, Blagoevgrad, 180-184. (in Bulgarian, Engl. summary).

Hristova, L., Spassov, N. (2005): Taxonomy and Ecology of the late Miocene Hipparions of

Bulgaria: Implication to the questions of the Balkans' Turolian biochronology and environmental changes. Neogene Climate and Vegetation Changes in Eastern Europe/Western Central Asia - the surrounding of the Black Sea. Annual NECLIME Meeting. Sofia 2005, October 1-4. Abstracts, (p. 14). Inst. of Botany. Bulg. Acad. Sci. KAUP, J.-J. (1832): Uber Rhinoceros incisivus CUV. und eine neue Art, Rhinoceros schleiermacheri. - Isis, 8: 898-904.

KAUP, J.-J. (1834): Description d'ossemens fossiles de Mammifères qui se trouvent au musée grand-ducal de Darmstadt. Heyer, Darmstadt, $3^{\text {ème }}$ cahier: p. 33-64.

KAYA, T. \& HEISSIG, K. (2001): Late Miocene Rhinocerotids (Mammalia) from Yulaflı (Çorlu Thrace/Turkey). - Geobios, 34: 457-467.

Kojumdjeva, E., Stoykov, S., Markova, S. (1984): Lithostratigraphy of the Neogene sediments of the Tundja (Elhovo-Jambol) basin - Spisanie na bulgarskoto geolojko drujestvo 45: 287-295.

KorotKeVich, O. L. (1958a): On certain structural features of the limbs in the Sarmatian Chilotherium. - Dopovidi Akad. Nauk Ukrainskoi RSR, 4: 467-470 [in Ukrainian]. KorotKeVich, O. L. (1958b): A new Chilotherium species from the Sarmatian deposits of the Ukraine. - Dopovidi Akad. Nauk Ukrainskoi RSR, 12: 1372-1376 [in Ukrainian]. KoRotKevich E. L. (1970): The mammals of the Berislav late Sarmatian hipparion-fauna. In: The Natural Environment and the fauna of the past. - Naukova Dumka, Kiev, 5: 24-121. KorotKeVICH, E. L. (1988): History of the formation of the Hipparion-fauna of East Europe. Naukova Dumka, Kiev, 161 pp. (in Russian).

Kostopoulos, D. S., Spassov, N. \& KovacheV, D. (2001): Contribution to the study of Microstonyx: evidence from Bulgaria and the SE European populations. - Geodiversitas, 23: 411-437.

Koufos, G. D., Spassov, N. \& Kovachev, D. (2003): Study of Mesopithecus (Primates, Cercopithecidae) from the late Miocene of Bulgaria. - Palaeontographica A, 269: 39-91. KovacheV, D. (1988): Indarctos bakalovi sp. n. (Ursidae) du Méotien près du village Kalimanci (Sud-Ouest de la Bulgarie). - Rev. Bulg. Geol. Soc., 49: 65-73. 
Kovachev, D. (2001): Description d'un squelette complete de Metailurus (Felidae, Carnivora, Mammalia) du Miocène supérieur de Bulgarie. - Geol. Balcan., 31: 71-88.

KrakhmalnayA T. (1996): The Hipparion-fauna of the ancient Maeotian of the North periPontic region. Naukova Dumka, Kiev, 225 p [in Russian, English summary].

KRETzOI, M. (1942): Bemerkungen zum System der Nachmiozänen Nashorn-Gattungen. Földtani Közlöny, 72: 309-318.

MARKOV, G. N. (2004a): The fossil proboscideans of Bulgaria and the importance of some Bulgarian finds. - Hist. nat. bulg., 16: 139-150.

Markov, G. N. (2004b): The fossil Proboscideans of Bulgaria. Unpubl. PhD Thesis, Sofia, 225 p. [in Bulgarian with English summary].

MARKOV G. N. (in press). Gomphotherium angustidens (Proboscidea, Mammalia) in Bulgaria Historia naturalis bulgarica, 18.

Merceron G., A. Zazzo, N. Spassov, D. Geraads, D. Kovachev (2006): Paleoecology and paleoenvironments from the Late Miocene of Bulgaria: evidence from dental microwear and stable isotopes - Palaeogeography, Palaeoclimatology, Palaeoecology, 241: 637-654.

Nikolov, I. (1973): The Genus Hipparion in Bulgaria. Ph.D. Thesis. Inst. of Geology, Bulg. Acad. Sci. [in Bulgarian].

Nikolov, I. (1985): Catalogue of the localities of tertiary Mammals in Bulgaria. - Paleont. stratigr. lithol., 21: 43-62.

Nikolov, I., KovacheV, D. (1966): Pliocene Mammal Fauna from Assenovgrad Region Travaux sur la géologie de Bulgarie, Ser. Paléontologie. - Acad. Bulg. Sci. Sofia, 8: 131 - 142 [in Bulgarian, German summary].

Pavlow, M. (1913-1914): Mammifères Tertiaires de la Nouvelle Russie. - Nouveaux Mémoires de la Société Impériale des Naturalistes du Moscou, 1ère partie. 17(3): 1-67. 2ème partie. 17(4): $1-52$.

RingSTRÖM, T. (1924): Nashörner der Hipparion-Fauna Nord-Chinas. - Palaeont. Sin., C, 1(4): $1-156$.

Roger, O. (1900): Ueber Rhinoceros goldfussi, Kaup und die anderen gleichzeitigen Rhinocerosarten. - Ber. Naturwiss. Ver. Schwaben Neuburg, 34: 1-52.

Roger, O. (1904): Wirbeltierreste aus dem Obermiocän der bayerisch-schwäbischen Hochebene. - Ber. Naturwiss. Ver. Schwaben Neuburg, 36: 1-21.

SCHAURTE W. (1966): Beiträge zur Kenntnis des Gebisses und Zahnbaues der afrikanischen Nashörner. Säugetierk. Mitt.- 14: 327-341.

Spassov, N. (2002): The Turolian Megafauna of West Bulgaria and the character of the Late Miocene "Pikermian biome". - Boll. Soc. Paleont. Ital., 41: 69-81. 
Spassov, N. \& GERAADS, D. (2004): Tragoportax Pilgrim and Miotragocerus Stromer

(Mammalia, Bovidae) from the Turolian of Hadjidimovo, Bulgaria, and a revision of the Late Miocene Mediterranean Boselaphini. - Géodiversitas, 26(2): 339-370.

Spassov, N. \& GinsBURG, L. (1999): Tapirus balkanicus nov.sp., nouveau tapir (Perissodactyla, Mammalia) du Turolien de Bulgarie. - Annls Paléont., 85: 265-276.

Spassov, N., TzAnKOV, Tz. \& GERAADS, D. (2006): Late Neogene stratigraphy, biochronology, faunal diversity and environments of South-West Bulgaria (Struma River valley). Géodiversitas, 28(3): 477-498.

ŞTIUCA, E (2003): Note préliminaire sur les mammifères du Miocène de Reghiu (Dept. Vrancea, Roumanie). - In: Petculescu A. \& ŞTiUCA E. (eds.), Advances in Vertebrate Paleontology "Hen to Panta". - Pp 113-116, "E. Racovita" Institute of Speleology, Bucharest:.

TASSY, P. (1983): Les Elephantoidea miocènes du plateau du Potwar, groupe de Siwalik, Pakistan. - Annales de Paléontologie (Vert.- Invert.), 69(2): 99-136; 69 (3): 235-297; 69 (4): $317-354$.

TASsy, P. (2003): Elephantoidea from Lothagam. - In: LEAKEY, M. G. \& HARRIS, J. M. (Eds.): Lothagam - The dawn of Humanity in Eastern Africa.- pp. 331-358, Columbia Univ. Press, New York.

Toula, F. (1906): Das Gebiss und Reste der Nasenbeine von Rhinoceros (Ceratorhinus Osborn) hundsheimensis. - Abh. kaiser.-könig. geol. Reichsanst., 20: 1-38.

Tzankov Tz., Spassov, N., Stoyanov, K. (2005): Neogene-Quaternary Paleogeography and Geodynamics of the region of Middle Struma river valley (South-Western Bulgaria). Publ. House of the South-Western University “N. Rilski”. Blagoevgrad). p. 199.

VACEK, M. (1900): Ueber Säugethierreste der Pikermifauna von Eichkogel bei Mödling. - Jb. geol. Reichanst. Wien, 50: 170-186.

VATSEV, M. (1980): Lithostratigraphy of the Neogene sedimentary rocks of the Gotse Delchev basin - Annual of the Higher Institute of Mining and Geology, 25: 103-115.

WeBER, M. (1904-1905): Über tertiäre Rhinocerotiden von der Insel Samos. - Bull. Soc. Impér. Natur. Moscou, 17(4): 477-501; 18(4): 344-363. 


\section{Captions to figures}

Fig. 1. Map of Bulgaria with the main rhino-bearing localities.

Fig. 2. Schematic drawing of the skull of Dihoplus pikermiensis from Strumyani.

Fig. 3. Map of the Balkano-Turkish region with the main occurrences of Turolian rhinoceroses.

Captions to plates.

P1. 1. A: Chilotherium (Eochilotherium) cf. kiliasi. Skull from Kromidovo, ventral view. B: same specimen, occlusal view of tooth-row. C: Chilotherium cf. kowalevskii. Left P3 FM-2700 and right (reversed) P4 FM-2699 from Yambol, occlusal view. D: Chilotherium sp., M3 A-1030 from Ahmatovo. E: Brachypotherium sp. P4, A- 620, from Ahmatovo. F: Brachypotherium sp. Upper tooth-row A-599 from Ahmatovo. G-H: Dihoplus pikermiensis, FM-2469 from Strumyani. G: detail of right auditory region. H: right upper tooth-row P4-M3. I-J: Dihoplus pikermiensis, FM-2470 from Strumyani. I: dorsal view. J: front view of the incisors. Scale $=25$ $\mathrm{cm}$ for Figs. A and I, $15 \mathrm{~cm}$ for Fig. G, $10 \mathrm{~cm}$ for all others.

P1. 2. Acerorhinus sp. A: Skull from Kalimantsi, K-595, lateral view. B: same specimen, occlusal view of tooth-row. C: same specimen, dorsal view. D: mandible from Kalimantsi, K-608, dorsal view. E: same specimen, lateral view. Scale $=10 \mathrm{~cm}$ for Fig. B, $20 \mathrm{~cm}$ fort all others.

P1. 3. A: Ceratotherium neumayri. Skull from Kalimantsi, K-594, lateral view. B: same specimen, occlusal view of tooth-row. C-F: Dihoplus pikermiensis. C: Occlusal view of toothrow from Hadjidimovo, HD-598. D: Occlusal view of upper deciduous cheek-teeth from Hadjidimovo, HD-607. E: mandible from Hadjidimovo, dorsal, view, HD-615. F: same specimen, lateral view. Scale $=20 \mathrm{~cm}$ for Fig. A, $10 \mathrm{~cm}$ for all others. 
Table 1. Measurements of upper tooth series (occlusal lengths)

\begin{tabular}{|l|c|c|c|c|}
\hline \multirow{2}{*}{ Acerorhinus sp. } & & P2-P4 & M1-M3 & P2-M3 \\
\cline { 2 - 5 } & K-595 & 123 & 127 & 240 \\
\cline { 2 - 5 } C. (E.) kiliasi & DGUS & 130 & 138 & - \\
\hline Brachypotherium sp. & Kromidovo & 107 & 130 & - \\
\hline Dihoplus pikermiensis & A-599 & 125 & 170 & 280 \\
\cline { 2 - 5 } & Strumyani & - & 153 & - \\
\cline { 2 - 5 } & HD-598 & 123 & 148 & 272 \\
\cline { 2 - 5 } & HD-606 & - & 142 & - \\
\cline { 2 - 5 } & HD-605 & - & 146 & - \\
\hline Ceratotherium neumayri & K-594 & 118 & 141 & 251 \\
\hline
\end{tabular}

Table 2. Measurements of mandibles

\begin{tabular}{|l|l|c|c|c|c|c|}
\hline & & $\begin{array}{c}\text { Overall } \\
\text { length }\end{array}$ & $\begin{array}{c}\text { depth from } \\
\text { ventral border } \\
\text { to sigmoid notch }\end{array}$ & $\begin{array}{c}\text { length } \\
\text { of } \\
\text { diastema }\end{array}$ & $\begin{array}{c}\text { length } \\
\text { of } \\
\text { symphysis }\end{array}$ & $\begin{array}{c}\text { width } \\
\text { of } \\
\text { symphysis }\end{array}$ \\
\hline Ch. kowalevskii & FM-2697 & - & - & - & - & ca. 120 \\
\hline Ch. kowalevskii & FM-2698 & & 188 & & & \\
\hline Acerorhinus sp. & K-608 & 530 & 167 & 35 & 130 & 105 \\
\hline D. pikermiensis & HD-615 & 550 & 230 & - & 130 & 60 \\
\cline { 2 - 7 } & FM-2470 & 630 & 235 & 106 & 151 & 70 \\
\hline C. neumayri & FM-2468 & 550 & 172 & 63 & 121 & ca. 90 \\
\hline
\end{tabular}

Table 3. Measurements of lower tooth series (occlusal lengths)

\begin{tabular}{|l|l|l|c|c|c|}
\hline & & & $\mathrm{p} 2-\mathrm{p} 4$ & $\mathrm{~m} 1-\mathrm{m} 3$ & $\mathrm{p} 2-\mathrm{m} 3$ \\
\hline Ch. kowalevskii & Yambol & FM-2697 & 88 & - & - \\
\cline { 3 - 6 } & & FM-2698 & - & 119.5 & - \\
\hline Acerorhinus sp. & \multirow{2}{*}{ Kalimantsi } & K-608 & 111 & 132 & - \\
\cline { 3 - 6 } & & DGUS & 119 & 139 & - \\
\hline D. pikermiensis & Strumyani & FM 2470 & 109 & 156 & 264 \\
\cline { 2 - 6 } & Hadjidimovo & HD-615 & 107 & 155 & 270 \\
\hline C. neumayri & Strumyani & FM 2468 & 108 & 154 & 268 \\
\hline
\end{tabular}


Table 4. Measurements of D. pikermiensis skulls

\begin{tabular}{|l|l|c|c|c|c|c|c|c|c|}
\hline \multicolumn{2}{|l|}{} & Strumyani & \multicolumn{9}{|c|}{ Pikermi } \\
\hline \multirow{2}{|l|}{ Guérin } & & $\begin{array}{c}\text { MNHNS } \\
\text { FM 2469 }\end{array}$ & $\begin{array}{c}\text { MNHN } \\
\text { B }\end{array}$ & M10141 & M10143 & M10144 & M10145 & $\begin{array}{c}\text { type } \\
\text { (cast) }\end{array}$ & $\begin{array}{c}\text { IPUW } \\
375\end{array}$ \\
\hline $\mathbf{3}$ & occipito-nasal length & 685 & $700-$ & 650 & $620+$ & & 660 & 620 & \\
\hline $\mathbf{4}$ & length of nasal incisure & 175 & 175 & 175 & 165 & & 160 & 150 & \\
\hline $\mathbf{9}$ & length orbit-nasal notch & 145 & 165 & 140 & 155 & 150 & 155 & 130 & \\
\hline $\mathbf{1 3}$ & length condylo-M3 & 320 & 310 & & & & & 295 & 295 \\
\hline $\mathbf{1 5}$ & width of nuchal crest & 215 & 210 & 170 & & & $150+$ & $130+$ & 150 \\
\hline $\mathbf{1 6}$ & post-tympanic width & $205+$ & 275 & 240 & 210 & 235 & 220 & $195+$ & $190+$ \\
\hline $\mathbf{2 3}$ & occipital height & 142 & & & & & 150 & 155 & 150 \\
\hline & length condylo-P2 & 590 & & & 505 & 530 & 525 & 535 & \\
\hline
\end{tabular}

Table 5. Measurements of upper milk-teeth

\begin{tabular}{|c|c|c|c|c|c|c|}
\hline & & DP1-DP4 & DP1 & DP2 & DP3 & DP4 \\
\hline $\begin{array}{l}\text { Brachypotherium } \\
\text { sp. }\end{array}$ & DGUS & 161 & - & $\begin{array}{c}41.5 \mathrm{x} \\
42.7\end{array}$ & $48.5 \times 52.4$ & $56.5 \times 57.5$ \\
\hline \multirow[t]{5}{*}{ D. pikermiensis } & HD-597 & 147.5 & $\begin{array}{c}27.3 \mathrm{x} \\
21.8\end{array}$ & $37 \times 33.6$ & $45 \times 43.1$ & $50.7 \times 45.2$ \\
\hline & HD-607 & 154.5 & $\begin{array}{c}29.5 \mathrm{x} \\
24.3\end{array}$ & $\begin{array}{c}40.7 \mathrm{x} \\
39.8\end{array}$ & $44.7 \times 46$ & $51.7 \times 48.6$ \\
\hline & K-601 & - & - & $39 \times 35$ & $44 \times 44$ & - \\
\hline & K-602 & - & $-\mathrm{x} 23.1$ & $39 \times 36$ & $-\mathrm{x} 46$ & - \\
\hline & K-604 & - & - & $38 x-$ & $-\mathrm{x} 42$ & $50.2 \times 40 *$ \\
\hline \multirow[t]{2}{*}{ C. neumayri } & K-593 & 145 & $\begin{array}{c}23.4 \mathrm{x} \\
20.6\end{array}$ & $37.2 \mathrm{x}-$ & $46.5 \times 44.6$ & $52.3 \times 44.3$ \\
\hline & K-603 & - & - & $-\mathrm{x} 33$ & $\begin{array}{l}46.1 \mathrm{x} \\
41 * *\end{array}$ & - \\
\hline
\end{tabular}

$*$ height of unworn metacone $=35.5$

$* *$ height of unworn metacone $=37.7$ 
Table 6: measurements of metapodials

\begin{tabular}{|c|c|c|c|c|c|c|c|}
\hline Locality & $\mathrm{N}^{\circ}$ & bone & length & $\begin{array}{l}\text { prox. } \\
\text { width }\end{array}$ & $\begin{array}{l}\text { prox. } \\
\text { depth }\end{array}$ & $\begin{array}{c}\text { dist. } \\
\text { width }\end{array}$ & $\begin{array}{l}\text { dist. } \\
\text { depth }\end{array}$ \\
\hline HD- & 517 & Mt-II & 157 & 33.4 & & 37.3 & 44.7 \\
\hline HD- & 516 & Mt-III & 180 & 59.4 & 51.6 & 53.5 & 45 \\
\hline HD- & 515 & Mt-IV & 148 & 47 & 45.5 & 39 & 45 \\
\hline HD- & 505 & Mt-II & 162 & 34.2 & 48.2 & 40 & 44.7 \\
\hline HD- & 533 & Mt-II & 151 & 31.8 & 45.7 & 37.8 & 43.3 \\
\hline HD- & 509 & Mt-II & 165 & 35.6 & 47.5 & 38 & 42.5 \\
\hline HD- & 504 & Mt-II & 155 & 33.5 & 46.1 & 39 & 42.5 \\
\hline HD- & 524 & Mt-III & 170 & & 49 & 55 & 44 \\
\hline HD- & 536 & Mt-III & 181 & & & & \\
\hline HD- & 622 & Mt-III & 188 & 61 & 55 & 55.5 & 44.5 \\
\hline HD- & 501 & Mt-III & 185 & & 47 & 52 & 42 \\
\hline HD- & 508 & Mt-III & 180 & 53 & & 54 & \\
\hline HD- & 571 & Mt-IV & & 47.7 & 46 & & \\
\hline HD- & 532 & Mt-IV & 162 & 55 & 45.5 & & 42.5 \\
\hline HD- & 623 & Mt-IV & 147 & & 43 & & 46 \\
\hline HD- & 530 & Mt-IV & & 50 & 49 & & \\
\hline HD- & 576 & Mt-IV & & 53 & 43 & & \\
\hline K- & $\begin{array}{l}\text { no } \\
\mathrm{N}^{\circ} \\
\end{array}$ & Mt-III & 172 & & 43.4 & 51.5 & 40.3 \\
\hline HD- & 512 & Mc-II & 168 & 41 & 52 & 44.8 & 47.2 \\
\hline HD- & 513 & Mc-III & 199 & 73.5 & 60.5 & 66.5 & 49.5 \\
\hline HD- & 514 & Mc-IV & 150 & - & 45 & 46.5 & 46.6 \\
\hline HD- & 507 & Mc-II & 183 & 50.8 & 49.6 & 44 & 48.6 \\
\hline HD- & 510 & Mc-II & 180 & & & & 48.5 \\
\hline HD- & 502 & Mc-II & 176 & 51 & 53 & 43.6 & 47.4 \\
\hline HD- & 535 & Mc-II & 158 & & & 44.5 & 45.6 \\
\hline HD- & 524 & Mc-III & 194 & 67 & & & \\
\hline HD- & 529 & Mc-III & 213 & 68 & 60 & & \\
\hline HD- & 523 & Mc-III & 210 & 65 & 52.8 & 59.5 & 60.5 \\
\hline HD- & 531 & Mc-IV & 160 & & & 41.2 & 47 \\
\hline HD- & 625 & Mc-IV & 170 & 56.5 & 43.2 & 44.5 & 48.5 \\
\hline HD- & 506 & Mc-IV & 170 & 57 & 41.3 & 44.5 & 49.9 \\
\hline K- & $\begin{array}{l}\text { no } \\
\mathrm{N}^{\circ} \\
\end{array}$ & Mc-IV & 145 & & 52.7 & 43.3 & 45.8 \\
\hline K- & 629 & Mc-II & 164 & 38 & 47 & 42 & 43 \\
\hline
\end{tabular}


Table 7. Measurements of Ceratotherium skulls

\begin{tabular}{|l|l|c|c|c|}
\hline Guérin & measurement & $\begin{array}{c}\text { C. simum } \\
\text { mean }\end{array}$ & $\begin{array}{c}\text { C. neumayri } \\
\text { mean }\end{array}$ & K-594 \\
\hline $\mathbf{8}$ & length occipito-orbital & 486 & 401 & 417 \\
\hline $\mathbf{9}$ & length orbit-nasal notch & 182 & 153 & 145 \\
\hline $\mathbf{1 3}$ & length condylo-M3 & 374 & 316 & 320 \\
\hline $\mathbf{1 5}$ & width of nuchal crest & 224 & 214 & 220 \\
\hline $\mathbf{1 6}$ & post-tympanic width & 257 & 233 & 220 \\
\hline $\mathbf{2 1}$ & bizygomatic width & 339 & 294 & 320 \\
\hline $\mathbf{2 2}$ & minimum nasal width & 164 & 150 & - \\
\hline $\mathbf{2 3}$ & occipital height & 169 & 152 & - \\
\hline $\mathbf{3 2}$ & bicondylar width & 155 & 131 & 124 \\
\hline & length condylo-orbital & - & - & 380 \\
\hline & length condyle-nasal notch & - & - & 520 \\
\hline
\end{tabular}

